\title{
Faktor risiko kejadian stunting pada anak umur 2-5 tahun di Puskesmas Biromaru
}

Risk factors on stunting among children age 2-5 years old in Biromaru of center public health

\author{
Imelda $^{1 *}$, Nurdin Rahman², Rosmala Nur ${ }^{1}$ \\ ${ }^{1}$ Program Studi Kesehatan Masyarakat, Fakultas Kesehatan Masyarakat, Universitas Tadulako, Palu \\ 2Program Studi Gizi, Fakultas Kesehatan Masyarakat, Universitas Tadulako, Palu
}

E-mail: imeldamuhlis@yahoo.co.id

Naskah diterima : 04-07-2018

Naskah diterbitkan:07-07-2018

\section{ABSTRACT}

Background \& Objective: Stunted is a condition of disruption of growth in children caused by chronic malnutrition. Prevalence of stunting in Sigi regency is 45,20\% (2015) and stunting incidence in Puskesmas Biromaru for children aged 2-5 are 60 cases (2017). This study aims to determine the risk factors of stunting events in children aged 2-5 years. Materials and Methods: Types of analytical survey research with Case Control design. Sampling method with total sampling and purposive sampling control sample based on certain consideration with ratio 1: 2, with case sample in this research as many as 60 children and control samples as much as 120 , each sample is chosen based on age as matching. Stunting degree expressed by $z$-score height by age. Complete basic immunization data, feeding practice patterns, low birth weight and iodized salt obtained through interviews using a questionnaire and iodine test. The analysis used is the odd ratio with a significance level of $95 \%$. Results: Complete basic immunization of OR 7,667 (95\% CI 3,753$15,662)$, practice pattern of feeding OR 30,565 (95\% CI 9.043-103,314), low birth weight OR 6,956 $(95 \%$ CI 4,446-14,104) and iodized salt OR 8,632 (95\% CI 4,268-17,456) is a risk factor for stunting events and has a significant relationship. Conclusion: Practice pattern of feeding is a major risk factor for stunting with OR 30,565.

Keywords: Complete Basic Immunization, Feeding Practice Patterns, Low Birth Weight, Iodized Salt, Stunting

\section{ABSTRAK}

Pendahuluan \& Tujuan: Stunting merupakan suatu kondisi terganggunya pertumbuhan pada anak yang disebabkan oleh malnutrisi kronik. Prevalensi stunting di Kabupaten Sigi sebanyak 45,20\% (2015) dan kejadian stunting di Puskesmas Biromaru untuk anak umur 2-5 sebanyak 60 kasus (2017). Penelitian ini bertujuan untuk mengetahui faktor risiko kejadian stunting pada anak umur 2-5 tahun. Bahan dan Metode: Jenis penelitian survey analitik dengan rancangan Case Control. Cara pengambilan sampel kasus dengan cara total sampling dan sampel kontrol purposive sampling berdasarkan pertimbangan tertentu dengan perbandingan 1:2, dengan sampel kasus pada penelitian ini sebanyak 60 anak dan sampel kontrol sebanyak 120, setiap sampel yang dipilih berdasarkan umur sebagai matching. Derajat stunting dinyatakan dengan $z$-score tinggi badan menurut umur. Data imunisasi dasar lengkap, pola asuh praktik pemberian makan, berat badan lahir rendah dan garam beryodium yang diperoleh melalui wawancara dengan menggunakan kuesioner dan test yodium. Analisis yang digunakan yaitu odd ratio dengan tingkat kemaknaan 95\%. Hasil: Imunisasi dasar lengkap OR 7,667 (CI 95\% 3,753-15,662), pola asuh praktik pemberian makan OR 30,565 (CI 95\% 9,043-103,314), berat badan lahir rendah OR 6,956 (CI 95\% 4,446-14,104) dan garam beryodium OR 8,632 (CI 95\% 4,268-17,456) merupakan faktor risiko kejadian stunting dan mempunyai hubungan yang bermakna. Kesimpulan: Pola asuh praktik pemberian makan merupakan faktorutama terhadap kejadian stunting dengan OR 30,565.

Kata Kunci: Imunisasi Dasar Lengkap, Pola Asuh Praktik Pemberian Makan, Berat Badan Lahir Rendah, Garam Beryodium, Stunting 


\section{A. Pendahuluan}

Stunting (pendek) merupakan ganguan pertumbuhan linier yang disebabkan adanya malnutrisi asupan zat gizi kronis atau penyakit infeksi kronis maupun berulang yang ditunjukkan dengan nilai $z$-score tinggi badan menurut umur (TB/U) <-2 SD (Kementerian Kesehatan, 2013).

Dampak buruk yang dapat ditimbulkan dari masalah gizi tersebut, dalam jangka pendek yaitu terganggunya perkembangan otak, kecerdasan, gangguan pertumbuhan fisik dan gangguan metabolism dalam tubuh. Sedangkan dalam jangka panjang yaitu menurunnya kemampuan kognitif dan prestasi belajar, menurunnya kekebalan tubuh sehingga mudah sakit dan berisiko tinggi munculnya penyakit diabetes, kegemukan, penyakit jantung dan pembuluh darah, kanker, stroke dan disabilitas pada usia tua serta kualitas kerja yang tidak kompetitif yang berakibat pada rendahnya produktivitas ekonomi (Kementerian Kesehatan, 2016).

Stunting secara global dalam kategori Very High umur 0-59 bulan terjadi di 21 negara yaitu terdapat di Timur Leste 58\%, Burundi 58\%, Niger 51\%, Madagascar 50\%, India 48\%, Guatamala 48\%, Malawi 47\%, Zambia 45\%, Ethiopia 44\%, Sierra Leone 44\%, Rwanda 44\%, Pakistan 44\%, Democratic Republic of the Congo 43\%, Mozambique 43\%, United Republic of Tanzania 42\%, Liberia 42\%, Bangladesh $41 \%$, Central Republic African $41 \%$, Nigeria $41 \%$, Nepal $41 \%$ dan Guinea $41 \%$ (United Nation Children Emergency Fund, 2013).

Data Riskesdas secara nasional prevalensi pendek tahun 2007 sebanyak $36,8 \%$ dan terjadi penurunan pada tahun 2010 sebanyak 35,6\% dan terjadi peningkatan lagi pada tahun 2013 sebanyak 37,2\% (Dinas Kesehatan Provinsi Sulawesi Tengah, 2015). Prevalensi stunting di Sulawesi Tengah sebesar $51 \%$ dan tertinggi berada di wilayah Kabupaten Sigi 45,2\% (Jastal dkk, 2013). Data stunting di Kabupaten Sigi sebanyak 45,20\%. Desa Maranatha, Desa Sidera dan Desa Jono Oge merupakan desa dengan kasus stunting yang tertinggi di Puskesmas Biromaru yakni 92 kasus (Dinas Kesehatan Kabupaten Sigi, 2015), dan terdapat 60 kasus stunting untuk anak umur 2-5 tahun.

Studi pendahuluan yang dilakukan pada 11 balita, 3 diantaranya tidak di imunisasi dasar lengkap, 9 anak dengan pola asuh praktik pemberian makan tidak baik, 6 anak termasuk anak dengan berat badan lahir rendah dan 2 anak mengonsumsi garam yang tidak mengandung yodium.

Penelitian ini bertujuan untuk menganalisis faktor risiko kejadian stunting pada anak umur 2-5 tahun di wilayah kerja Puskesmas Biromaru Kabupaten Sigi.

\section{B. BAHAN DAN METODE}

\section{Desain Penelitian}

Jenis penelitian yang digunakan adalah case control.

\section{Populasi dan Subjek Penelitian}

Jumlah responden yaitu 180 responden dengan perbandingan 1:2 (60 kasus dan 120 kontrol), pengambilan sampel menggunakan teknik purposive sampling dengan umur sebagai matching.

\section{Pengumpulan data}

Data imunisasi dasar lengkap dan pola asuh praktik pemberian makan, berat badan lahir rendah dan garam beryodium diperoleh melalui wawancara menggunakan kuesioner dan test yodium.

\section{Analisa Data}

Analisis data yang digunakan yaitu odd ratio dengan tingkat kemaknaan 95\%.

\section{HASIL}

Hasil analisis Odds Ratio OR dengan confidence interval 95\% menunjukkan adanya risiko imunisasi dasar lengkap terhadap stunting $\mathrm{OR}=7,667(3,753-15,662)$, pola asuh praktik pemberian makan terhadap stunting $\mathrm{OR}=30,565(9,043-103,314)$, berat badan lahir rendah terhadap stunting $\mathrm{OR}=6,956$ $(4,446-14,104)$ sedangkan garam beryodium OR $=8,632(4,268-17,456)$.

\section{PEMBAHASAN}

\section{Imunisasi Dasar Lengkap}

Pada penelitian ini diperoleh hasil bahwa imunisasi dasar lengkap merupakan faktor risiko stunting, terlihat pada (tabel 1) bahwa kelompok kasus jumlah anak yang tidak mendapatkan imunisasi dasar lengkap 76,7\% lebih banyak dibandingkan dengan anak yang mendapatkan imunisasi dasar lengkap 23,3\%, sebaliknya pada kelompok kontrol jumlah anak lebih banyak mendapatkan imunisasi dasar lengkap 70\% dibandingkan yang tidak mendapatkan imunisasi dasar lengkap 30\%.

Imunisasi dapat memberikan antigen bakteri atau virus tertentu yang telah dilemahkan atau dimatikan dengan tujuan merangsang sistem imun tubuh untuk membentuk antibodi. Antibodi yang terbentuk setelah imunisasi berguna untuk meningkatkan kekebalan seseorang secara aktif sehingga dapat mencegah atau 
mengurangi penyakit tertentu (Kementerian Kesehatan, 2016). Imunisasi bermanfaat untuk melindungi bayi dan balita dari penyakit infeksi yang berbahaya seperti TBC, Hepatitis B, Difteri, Pertusis, Tetanus dan Campak (Kementerian Kesehatan, 2011). Infeksi yang menghambat reaksi imunologis yang normal dengan menghabiskan energi tubuh. Apabila balita tidak memiliki imunitas terhadap penyakit, maka balita akan lebih cepat kehilangan energi tubuh karena penyakit infeksi, sebagai reaksi pertama akibat adanya infeksi adalah menurunnya nafsu makan anak sehingga anak menolak makanan yang diberikan ibunya. Penolakan terhadap makanan berarti berkurangnya pemasukan zat gizi dalam tubuh anak (Anhari, 2008).

Tabel 1. Distribusi Kejadian Stunting Di Wilayah Kerja Puskesmas Biromaru Kecamatan Sigi Biromaru Kabupaten Sigi

\begin{tabular}{|c|c|c|c|c|c|}
\hline \multirow{3}{*}{ Faktor Risiko } & \multicolumn{4}{|c|}{ Stunting } & \multirow{3}{*}{$\begin{array}{c}\text { OR } \\
\text { (CI 95\%) }\end{array}$} \\
\hline & \multicolumn{2}{|c|}{ Kasus } & \multicolumn{2}{|c|}{ Kontrol } & \\
\hline & $\mathbf{n}$ & $\%$ & $\mathbf{n}$ & $\%$ & \\
\hline \multicolumn{6}{|l|}{ Imunisasi Dasar Lengkap } \\
\hline Berisiko & 46 & 76,7 & 36 & 30 & $7,667(3,753-15,662)$ \\
\hline Tidak Berisiko & 14 & 23,3 & 84 & 70 & \\
\hline \multicolumn{6}{|c|}{ Pola Asuh Praktik Pemberian Makan } \\
\hline Berisiko & & & & & $30,565(9,043-103,314)$ \\
\hline Tidak berisiko & 57 & 95 & 46 & 38,3 & \\
\hline $\begin{array}{l}\text { Berat Badan Lahir Rendah } \\
\text { Berisiko }\end{array}$ & 3 & 5 & 74 & 61,7 & \\
\hline Tidak Berisiko & 44 & 73,3 & 34 & 28,3 & $6,956(4,446-14,104)$ \\
\hline Garam Beryodium & 16 & 26,7 & 86 & 71,7 & \\
\hline \multicolumn{6}{|l|}{ Berisiko } \\
\hline Tidak Berisiko & 41 & 68,3 & 24 & 20 & $8,632(4,268-17,456)$ \\
\hline & 19 & 31,7 & 96 & 80 & \\
\hline
\end{tabular}

Sumber : Data Primer, 2017

Penelitian sejalan yang dilakukan di India oleh Agarwal et al (2014) mendapatkan bahwa malnutrisi lebih banyak ditemukan pada anak yang tidak diimunisasi daripada anak yang diimunisasi (Agarwal et al., 2014).

\section{Pola Asuh Praktik Pemberian Makan}

Pada penelitian ini diperoleh hasil bahwa pola asuh praktik pemberian makan merupakan faktor risiko stunting, dapat dilihat pada tabel 1 yang menyatakan bahwa pada kelompok kasus jumlah anak yang tidak mendapatkan pola asuh praktik pemberian makan 95\% lebih banyak dibandingkan dengan anak yang mendapatkan pola asuh praktik pemberian makan 5\%, sebaliknya pada kelompok kontrol jumlah anak lebih banyak yang mendapatkan pola asuh praktik pemberian makan $61,7 \%$ dibandingkan anak yang tidak mendapatkan pola asuh praktik pemberian makan 38,3\%.

Asupan nutrisi pada anak memegang peranan penting dalam optimalisasi tumbuh kembang pada anak (Sulistyoningsih, 2011). Asupan nutrisi yang kurang akan menyebabkan kondisi kesehatan anak menjadi kurang baik, gangguan pertumbuhan dan perkembangan, serta dapat menyebabkan kematian (Barasi, 2009).

Penelitian sejalan yang dilakukan oleh Aryastami et al (2017), bahwa pemberian makanan komplementer yang tepat termasuk kualitas, keragaman dan keragaman setelah pemberian ASI eksklusif akan mendukung pertumbuhan bayi. Kelayakan didefinisikan sebagai jenis makanan yang tepat (semi padat sampai padat, yang mencakup sumber protein), komposisi nutrisi seimbang (energi, protein, vitamin dan mineral), praktik persiapan makanan yang tepat, serta perawatan anak yang tepat (Aryastami et al., 2017).

\section{Berat Badan Lahir Rendah}

Pada penelitian ini diperoleh hasil bahwa berat badan lahir rendah merupakan faktor risiko stunting, terlihat pada tabel 1 yang menunjukkan bahwa pada kelompok kasus jumlah anak lebih banyak yang mengalami berat badan lahir rendah 73,3\% dibandingkan dengan anak yang 26,7\% tidak mengalami berat badan lahir rendah, sebaliknya pada kelompok kontrol jumlah anak lebih banyak yang tidak mengalami berat badan lahir rendah $71,7 \%$ dibandingkan dengan anak yang mengalami berat badan lahir rendah 28,3\%.

Pada anak yang mengalami berat badan lahir rendah, zat anti kekebalan kurang sempurna sehingga lebih mudah terkena penyakit terutama penyakit infeksi. Penyakit ini menyebabkan balita kurang nafsu makan sehingga asupan makanan yang masuk kedalam tubuh menjadi berkurang dan dapat menyebabkan gizi buruk (Kosim, 2008). Penyebab terbanyak dari berat badan lahir rendah ini adalah bayi yang lahir prematur atau dapat disebabkan saat bayi mengalami hambatan saat di dalam kandungan. Dampak berat badan lahir rendah ini adalah meningkatkan risiko angka morbiditas (kesakitan) dan gangguan pertumbuhan fisik 
saat balita (Tim Paket Pelatihan Klinik Poned, 2008).

Penelitian sejalan yang dilakukan oleh Abuya et al (2012), bahwa anak dengan berat badan lahir kurang dari 2500 gram, memiliki risiko menjadi stunting sebesar 3,26 kali dibandingkan dengan anak yang lahir dengan berat badan normal (Abuya, Ciera, \& KimaniMurage, 2012).

\section{Garam Beryodium}

Pada penelitian ini diperoleh hasil bahwa garam beryodium merupakan faktor risiko stunting, terlihat pada tabel 1 yang menunjukkan bahwa pada kelompok kasus jumlah anak lebih banyak yang tidak mengonsumsi garam beryodium 68,3\% dibandingkan dengan anak yang mengonsumsi garam beryodium 31,7\%, sebaliknya pada kelompok kontrol jumlah anak lebih banyak yang mengonsumsi garam beryodium $80 \%$ dibandingkan dengan anak yang tidak mengonsumsi garam beryodium $20 \%$.

Yodium merupakan bagian integral dari kedua macam hormone tiroksin triiodotironin (T3) dan tetraiodotironin (T4). Fungsi utama hormon-hormon ini adalah mengatur pertumbuhan dan perkembangan. Hormon tiroid mengontrol kecepatan pelepasan energi dan zat gizi yang menghasilkan energi. Tiroksin dapat merangsang metabolisme sampai 30\%. Disamping itu kedua hormon ini mengatur suhu tubuh, reproduksi, pembentukan sel darah merah serta fungsi otot dan saraf, apabila kadar senyawa T3 kurang akibat kebutuhan yodium yang tidak tercukupi, maka laju metabolisme basal sel akan rendah sehingga proses tumbuh kembang menjadi terganggu dan terhambat(Devi, 2012).

Penelitian sejalan yang dilakukan oleh Nwamarah et al (2012), bahwa stunting terjadi dimungkinkan karena efek dari penggunaan yodium rendah, meskipun mungkin ada faktor predisposing lainnya, seperti infeksi dan gizi buruk yang dapat menyebabkan stunting (Nwamarah, 2012). Penelitian yang dilakukan oleh Devi (2012), mendapatkan bahwa garam yang mengandung yodium menjadi faktor risiko kejadian stunting.

\section{E. KESIMPULAN}

Imunisasi dasar lengkap, pola asuh praktik pemberian makan, berat badan lahir rendah dan garam beryodium merupakan faktor risiko kejadian stunting dan mempunyai hubungan yang bermakna dengan kejadian stunting

\section{F. DAFTAR PUSTAKA}

Abuya, B. A., Ciera, J., \& Kimani-Murage, E. (2012). Effect of mother's education on child's nutritional status in the slums of Nairobi. BMC Pediatrics, 12, 80. https://doi.org/10.1186/1471-2431-1280

Agarwal, N., Sharma, R. P., Chandra, S., Varma, P., Midha, T., \& Nigam, S. (2014). Immunization status and childhood morbidities as determinants of PEM among under-five children in slums of Kanpur. Indian Journal of Community Health, 26(4), 396-400.

Anhari. (2008). Pemberian Makanan Untuk Bayi Dasar Dasar Fisiologi (Cetakan I). Jakarta: Binarupa Aksara.

Aryastami, N. K., Shankar, A., Kusumawardani, N., Besral, B., Jahari, A. B., \& Achadi, E. (2017). Low birth weight was the most dominant predictor associated with stunting among children aged 12-23 months in Indonesia. BMC Nutrition, 3, 16. https://doi.org/10.1186/s40795-0170130-x

Barasi. (2009). At A Glace Ilmu Gizi. Jakarta: PT. Glora Aksara Pratama.

Devi. (2012). Hubungan Penggunaan Garam Beryodium Dengan Pertumbuhan Linier Anak. Jurnal TIBBS (Teknologi Industri Boga Dan Busana), 3(1), 52-57.

Dinas Kesehatan Kabupaten Sigi. (2015). Laporan Penimbangan Gizi Kabupaten Sigi. Kabupaten Sigi: Dinas Kesehatan Kabupaten Sigi.

Dinas Kesehatan Provinsi Sulawesi Tengah. (2015). Data Stunting Tahun 2015. Palu: Dinas Kesehatan Provinsi Sulawesi Tengah.

Jastal dkk. (2013). Riset Kesehatan Dasar Dalam Angka (Riskesdas 2013) Provinsi Sulawesi Tengah. Badan Penelitian Dan Pengembangan Kesehatan, Kementerian Kesehatan Republik Indonesia.

Kementerian Kesehatan. (2011). Buku Panduan Kader Posyandu. Jakarta: Direktorat Jenderal Bina Gizi dan Kesehatan Ibu dan Anak.

Kementerian Kesehatan. (2013). Situasi Balita Pendek. Pusat Data dan Informasi. Jakarta: Kementerian Kesehatan RI.

Kementerian Kesehatan. (2016). Situasi Imunisasi di Indonesia. Info Datin Pusat Data dan Informasi. Jakarta: Kementerian Kesehatan RI.

Kosim. (2008). Buku Ajar Neonatologi Edisi I. Jakarta: Badan Penerbit IDAI.

Nwamarah, N. (2012). A pilot study of iodine 
and anthropometric status of primary school children in Obukpa, a rural Nigerian community. Journal of Public Health and Epidemiology, 4(9), 246-252. https://doi.org/10.5897/JPHE12.087

Sulistyoningsih. (2011). Pertumbuhan dan Perkembangan Anak dan Remaja. Jakarta: TIM.

Tim Paket Pelatihan Klinik Poned. (2008). Buku Acuan Pelayanan Obstetri dan
Neonatal Emergensi Dasar (PONED). Jakarta: EGC.

United Nation Children Emergency Fund. (2013). Improving Child Nutrition the Achievable Imperative For Global Progress. New York. 